\title{
EFFECT OF BASELLA ALBA ON GROWTH IN SCIENCE PERFORMANCE OF NILE TILAPIA (Oreochromis niloticus) FINGERLINGS.
}

\author{
${ }^{1}$ Department of Fisheries and Aquaculture \\ Technology, Federal University of \\ Technology Akure, Nigeria \\ 2 \\ Department of Biology, Adeyemi College \\ of Education Ondo, Nigeria.
}

Oladipupo Mathew ${ }^{1}$, Osungbemiro Nelson ${ }^{2}$, Bankole Gafar ${ }^{3}$, Sanni Rafiu.

\section{Correspondence}

Osungbemiro Nelson Rotimi, Department of Biology, School of Science, Adeyemi College of Education, Ondo, Nigeria.

Email:bronelsonto03@gmail.com

\begin{abstract}
:
Introduction: Tilapias (Family Cichlidae) are among the freshwater fish species suitable for aquaculture and widely cultivated globally because of their fast growth rate, efficient use of natural aquatic foods, propensity to consume a variety of supplementary feeds, omnivorous feeding habits, resistance to disease and handling, ease of reproduction in captivity, and tolerance to wide ranges of environmental conditions

Aims: Experiment was conducted to evaluate the growth performance ${ }^{\wedge}$ nutrient utilization of Oreochromis niloticus fed varying levels of Basella alba leave based diets.

Materials and Methods: $O$. niloticus fingerlings $(1.95 \pm 0.01 \mathrm{~g})$ were randomly selected and distributed into 15 glass tanks at the rate of 15 fish per tank representing five treatments and three replicates. Five diets were formulated to containing $(0,1.0,1.5,2.0$ and $2.5 \mathrm{~g} / 100 \mathrm{~kg}$ diets) of $B$. alba were prepared and fed to the fish for 70 days.

Results: The results revealed that weight gain, specific growth rate, feed intake and feed conversion ratio improved progressively up to the inclusion level of $2.0 \mathrm{~g} / 100 \mathrm{~g}$ of $\mathrm{B}$. alba leave meal and then declined indicating $2.0 \mathrm{~g} / 100 \mathrm{~g} \mathrm{~B}$. alba leave meal as the optimum level that can promote the growth performance of the fish. However, 4th degree polynomial regression analysis indicated the optimum level as about $2.1 \mathrm{~g} / 100 \mathrm{~g}$ diet. It was observed that there was no significant difference in the survival $(p>$ 0.05 ) of the fish fed diets with different $B$. alba leave meal.

Conclusion: Based on the results obtained from this present study, it could be concluded that $2.0-2.1 \mathrm{~g} / 100 \mathrm{~kg}$ of $B$. alba leave can be included in the diets of $O$. niloticus fingerlings for optimum growth performance. To Keywords: Nile tilapia, B. alba, growth performance, plant additives, in vitro.
\end{abstract}




\section{INTRODUCTION}

Tilapias (Family Cichlidae) are among the freshwater fish species suitable for aquaculture and widely cultivated globally because of their fast growth rate, efficient use of natural aquatic foods, propensity to consume a variety of supplementary feeds, omnivorous feeding habits, resistance to disease and handling, ease of reproduction in captivity, and tolerance to wide ranges of environmental conditions [1],[2],[3]. In recent year, herbal supplements as feed additives have been tested in aquaculture as an alternative to chemicals to enhance fish growth [4]. Using of plant-based additives in aquaculture is one of the methods used to improve weight gain and feed efficiency in cultured fish [4]. Beneficial effects of bioactive plant substances in animal nutrition may include the stimulation of appetite and feed intake, the improvement of endogenous digestive enzyme secretion, activation of immune responses and antibacterial, antiviral and antioxidant actions [5]. Ceylon spina (Basella alba), a fast growing vegetable, probably originating from India or Indonesia [6], has been reported to possess active components that increase testosterone production in adult male rat testes during in vitro studies [7]. The leaves contain a high level of calcium and are rich in vitamins like A, C, thaimine, riboflavin, niacin, and betacyanin, oxalic acid, flavonoid like acacetin, 4,7- dihydroxy kempferol and 4'methoxyisovitexin and also phenolic acids like vanilla, syringic and ferulic acid [8]. It also contains essential amino acids such as arginine, isoleucine, leucine, lysine, threonine, and tryptophan. B. alba has also been described to possess nutritional values including androgenecity in traditional medicines of several countries [9]. This present study was to investigate the potential effect of $B$. alba leave on the growth performance and nutrient utilization of $O$. niloticus.

\section{MATERIAL AND METHODS}

\subsection{Plant Material}

The fresh leaves of $(B$. alba) used in the study was harvested fresh from Ogunlade compound, Ibule-Soro, Ondo State. Nigeria. It was identified and authenticated at the Department of Crop, Soil and Pest Management, Federal University of Technology, Akure using plant identification guide provided by [10]. The leaves were washed thoroughly with running tab water, chopped into small pieces and dried at room temperature for 15 days to prevent the loss of volatile compounds. The dried leaves were ground into fine powder using pestle and mortar and stored at $4^{\circ} \mathrm{C}$ in sealed airtight bottle until used.

\subsection{Experimental Fish}

Five hundred (500) Oreochromis niloticus fingerlings were collected from the Fish Hatchery of The Federal University of Technology Akure. The experimental fish were acclimatized to laboratory conditions for one week. Fish were fed during the acclimatization period with commercial feed $(35 \% \mathrm{cp})$ to satiation twice daily. They were then starved for 24 hours prior to the beginning of the feeding trials. Fish were then weighed after subjecting to commercial diets and starving in order to determine the mean weight.

\subsection{Experimental Design}

The experimental design was a complete randomized design. Two hundred and twenty-five (225) O. niloticus fingerlings with mean weight of $1.95 \pm 0.01 \mathrm{~g}$ were randomly selected and distributed into 15 glass tanks (70litre) each measuring $(70 \mathrm{~cm} \times 45 \mathrm{~cm} \times 45 \mathrm{~cm})$ at the rate of 15 fish per tank representing five treatments and three replicates.

\subsection{Experimental Diets}

Five iso-nitrogenous diets (35\%CP) were formulated to containing $B$. alba at $(0.0,1.0,1.5,2.0$ and $2.5 \mathrm{~g} / \mathrm{kg})$ and labelled as BA1-BA5 (Table 1). Other feed ingredients include fishmeal, soya bean meal, groundnut cake, yellow maize, methionine, lysine, fish oil, vitamin premix, and starch as a binder. One portion of the feed was kept without $B$. alba incorporation which served as control. The $B$. alba leave meal was mixed thoroughly with other feed ingredients to ensure an equal distribution throughout the feed. The ingredients were weighed with an electronic weighing balance (Model PB3002). The dough was pelleted using a Horbart A200T mixing and pelleting machine using $2 \mathrm{~mm}$ die diameter. After making one diet, the machine was cleaned before making the next diet. Diets were fan dried under room temperature for 72 hours packed in polyethylene bags, sealed, and marked according to treatments and stored at $40 \mathrm{C}$ before use.

\subsection{Weighing of Experimental Fish}

The individual weight of each fish from each glass tank was determined immediately after acclimatization using an electronic weighing balance (model PB 3002). The mean weights of fish per tank were recorded. The weighing continued biweekly until the experiment was terminated.

TABLE 1: Gross composition of the experimental diets $(\mathrm{g} / 100 \mathrm{~g})$ for $O$. niloticus 


\begin{tabular}{lccccc}
\hline Ingredients & BA1 & BA2 & BA3 & BA4 & BA5 \\
Fish meal & 16.8 & 16.8 & 16.8 & 16.8 & 16.8 \\
(65\%cp) & & & & & \\
Soybean & 30.0 & 30.0 & 30.0 & 30.0 & 30.0 \\
meal(45\% & & & & & \\
CP) & & & & & \\
Ground nut & 22.1 & 22.1 & 22.1 & 22.1 & 22.1 \\
cake (48\% & & & & & \\
CP) & & & & & \\
Yellow maize & 18.6 & 18.6 & 18.6 & 18.6 & 18.6 \\
Methionine & 1.0 & 1.0 & 1.0 & 1.0 & 1.0 \\
Lysine & 1.0 & 1.0 & 1.0 & 1.0 & 1.0 \\
Fish oil & 5.0 & 5.0 & 5.0 & 5.0 & 5.0 \\
Vitamin & 3.5 & 3.5 & 3.5 & 3.5 & 3.5 \\
premix & & & & & \\
Starch & 2.0 & 2.0 & 2.0 & 2.0 & 2.0 \\
B. alba leave & 0.0 & 1.0 & 1.5 & 2.0 & 2.5 \\
& & & & & \\
\hline
\end{tabular}

\subsection{Feeding of Experimental Fish}

The diets were fed to the fish to apparent satiation, twice daily between 08:00 and 09:00 and 16:00 and 17:00 hours for 70 days. After each feeding all uneaten feeds was removed from the tanks by siphoning at 08:00 and 4:00 hours daily before feeding with culture water partially drained and replenished with fresh water. Culture water in experimental units were completely drained and changed twice a week.

\subsection{Monitoring of Water Quality}

Tank water was changed regularly to maintain good water quality. Temperature was measured using mercury glass thermometer. $\mathrm{pH}$ was measured with a $\mathrm{pH}$ meter (Jenway model 9060). Dissolved oxygen (DO) was measured using dissolved oxygen test kit (Hanna model: HI-9142). Calculation of the growth performance data was according to [11] and [12]. The proximate analysis of the $B$. alba leaves and experimental feed was done following the method of [13] while gross energy was calculated as $5.65,9.45,4.1 \mathrm{kcal} / \mathrm{g}$ for protein, fat and carbohydrate respectively [14].

\subsection{Statistical Analysis}

Data collected were subjected to one-way analysis of variance (ANOVA) as describe by [15] followed by Duncan new multiple range test [16] to separate differences among the means. The statistical analysis was performed with the aid of the computer software SPSS (Statistical Package for Social Science Version 22). The optimum concentration of $B$. alba required by LASU Journal of Research and Review in Science the fish for best performance was determined by polynomial regression analysis using (Microsoft Office Excel Programme 2010).

\section{RESULTS AND DISCUSSION}

The nutrient composition of $B$. alba leave meal is presented in Table 2. The result showed that $B$. alba has a low moisture content, this could be attributed to the period of sampling which was about onset of dry season/ the harmattan period, a season characterized by intensive sunlight and dryness. Moisture content of the fresh samples was $68.3 \%$ which is similar to results reported by [17] for some leafy vegetables. The result of this study compared favourably with that reported by [18] who reported that leafy vegetables have a moisture content ranging from 72 to $93 \%$. On dry matter basis, moisture content of $B$. alba in this study was $9.82 \%$. The high moisture content of vegetables indicates freshness and perishability, as well as indicating that they may play a key role in aiding the digestion of food [19]. It also has high ash content value which showed that the leave contained appreciable amount of mineral elements. It has higher crude protein (17.05\%). This justifies its use as a protein feed ingredient in animal production including fish. The lipid content is high enough to supply fats and oil to the diets. It also high in non-protein value that can be advantageous in energy supply.

TABLE 2: Proximate analysis of $B$. alba leave

\begin{tabular}{|l|l|l|}
\hline Parameters (\%) & shade dried & $\begin{array}{l}\text { Fresh, raw } \\
\text { leaves }\end{array}$ \\
\hline Moisture & 9.82 & 68.3 \\
\hline Ash & 23.10 & 25.1 \\
\hline Protein & 17.05 & 15.7 \\
\hline Fibre & 20.23 & 25.6 \\
\hline Lipid & 5.09 & 8.10 \\
\hline NFE & 24.71 & 42.8 \\
\hline
\end{tabular}

KEY: NFE= Nitrogen free extract

The water quality parameters measured during the feeding trial for 70 days varied as follows; temperature ranged from 26.4 to $27.9 \mathrm{oC}$, Dissolved oxygen ranged from 6.51 to $7.10 \mathrm{mg} / \mathrm{l}$ and hydrogen ion concentration $(\mathrm{pH})$ ranged from 6.51 to 7.58 respectively. The values of physic-chemical parameters observed in the glass tank were within the acceptable range recommended for rearing and culture of most fresh water fishes, including O. niloticus [20].

Results from proximate composition of the experimental diets are documented in Table 3 . The values are very 
closely related confirming good feed formulation. The values are also standard for production of tilapias [21].

TABLE 3: Proximate composition $(\mathrm{g} / \mathbf{1 0 0 \mathrm { g } )}$ of experimental diets

\begin{tabular}{llllll}
\hline Parameters & BA1 & BA2 & BA3 & BA4 & BA5 \\
\hline Moisture & 10.5 & 9.18 & 10.20 & 9.21 & 9.15 \\
Ash & 5.73 & 6.10 & 6.23 & 6.32 & 6.33 \\
Protein & 35.28 & 35.17 & 35.05 & 35.03 & 34.63 \\
Fibre & 4.54 & 5.22 & 5.39 & 5.62 & 5.75 \\
Lipid & 7.82 & 9.13 & 9.22 & 9.26 & 9.31 \\
NFE & 36.65 & 35.20 & 33.91 & 34.56 & 34.83 \\
GE & 423.86 & 429.66 & 424.56 & 427.47 & 423.67
\end{tabular}

Table 4: Growth performance of $O$. niloticus

\begin{tabular}{llllll}
\hline $\begin{array}{l}\text { Parame } \\
\text { ters }\end{array}$ & \multicolumn{1}{c}{ BA1 } & \multicolumn{1}{c}{ BA2 } & \multicolumn{1}{c}{ BA3 } & \multicolumn{1}{c}{ BA4 } & \multicolumn{1}{c}{ BA5 } \\
\hline \multirow{3}{*}{ IW } & $1.95 \pm 0$ & $1.95 \pm 0$. & $1.95 \pm 0$. & $1.95 \pm 0$. & $1.95 \pm 0$. \\
& $.01^{\mathrm{a}}$ & $01^{\mathrm{a}}$ & $02^{\mathrm{a}}$ & $01^{\mathrm{a}}$ & $01^{\mathrm{a}}$ \\
& $5.58 \pm 0$ & $5.69 \pm 0$. & $5.71 \pm 0$. & $5.74 \pm 0$. & $5.66 \pm 0$. \\
FW & $.30^{\mathrm{a}}$ & $22^{\mathrm{ab}}$ & $18^{\mathrm{c}}$ & $24^{\mathrm{b}}$ & $21^{\mathrm{ab}}$ \\
& $3.63 \pm 0$ & $3.74 \pm 0$. & $3.76 \pm 0$. & $3.79 \pm 0$. & $3.71 \pm 0$. \\
WG & $.29^{\mathrm{a}}$ & $07^{\mathrm{ab}}$ & $19^{\mathrm{c}}$ & $38^{\mathrm{b}}$ & $21^{\mathrm{ab}}$ \\
SGR & $1.50 \pm 0$ & $1.53 \pm 0$. & $1.53 \pm 0$. & $1.54 \pm 0$. & $1.52 \pm 0$. \\
(\%/day) & $.07^{\mathrm{a}}$ & $02^{\mathrm{ab}}$ & $05^{\mathrm{b}}$ & $06^{\mathrm{ab}}$ & $05^{\mathrm{b}}$ \\
& $6.08 \pm 0$ & $6.20 \pm 0$. & $6.22 \pm 0$. & $6.23 \pm 0$. & $6.16 \pm 0$. \\
FI & $.02^{\mathrm{a}}$ & $05^{\mathrm{b}}$ & $18^{\mathrm{c}}$ & $07^{\mathrm{b}}$ & $06^{\mathrm{ab}}$ \\
& $1.67 \pm 0$ & $1.66 \pm 0$. & $1.65 \pm 0$. & $1.64 \pm 0$. & $1.66 \pm 0$. \\
FCR & $.15^{\mathrm{a}}$ & $03^{\mathrm{a}}$ & $04^{\mathrm{a}}$ & $10^{\mathrm{a}}$ & $10^{\mathrm{a}}$ \\
& $0.60 \pm 0$ & $0.60 \pm 0$. & $0.60 \pm 0$. & $0.61 \pm 0$. & $0.60 \pm 0$. \\
FER & $.31^{\mathrm{a}}$ & $07^{\mathrm{b}}$ & $19^{\mathrm{b}}$ & $31^{\mathrm{b}}$ & $24^{\mathrm{b}}$ \\
Surviva & $97.8 \pm 2$ & $88.9 \pm 2$. & $100.0 \pm 0$ & $100.0 \pm 0$ & $100.0 \pm 0$ \\
I & $.23^{\mathrm{b}}$ & $20^{\mathrm{a}}$ & $.00^{\mathrm{b}}$ & $.00^{\mathrm{b}}$ & $.00^{\mathrm{b}}$ \\
\hline \multicolumn{5}{l}{ Mean in the same row with different letter are } \\
significantly different at $P<.05$ & &
\end{tabular}

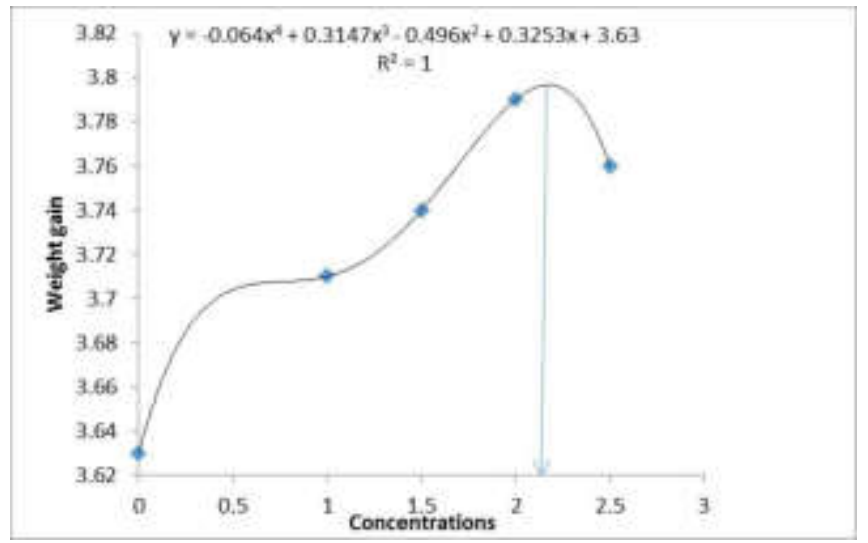

Fig. 1. Fourth degree polynomial regression analysis of WG to dietary $B$. alba

\section{CONCLUSION}

This study has shown that $B$. alba leaves can be tolerated by $O$. niloticus. The results revealed that weight gain, specific growth rate, feed intake and feed conversion ratio improved progressively up to the inclusion level of $2.0 \mathrm{~g} / 100 \mathrm{~g}$ of $B$. alba leave meal and then declined indicating $2.0 \mathrm{~g} / 100 \mathrm{~g} \mathrm{~B}$. alba leave meal as the optimum level that can promote the growth performance of the fish. It could be concluded that 2.0 $2.1 \mathrm{~g} / 100 \mathrm{~kg}$ of $B$. alba leave can be included in the diets of $O$. niloticus fingerlings for optimum growth performance. 


\section{AUTHORS' CONTRIBUTIONS}

Oladipupo Mathew designed the study, performed the statistical analysis, wrote the protocol, and wrote the first draft of the manuscript. Osungbemiro Nelson, Bankole Gafar and Sanni Rafiu managed the analyses of the study, managed the literature searches and typesetting. All authors read and approved the final manuscript.

\section{REFERENCES}

1. Fagbenro, OA. A review of biological and economic principles underlying commercial fish culture production in Nigeria. Journal of West African Fisheries. 1987;3: 171-177.

2. Satia, BP. National reviews for aquaculture development in Africa. 29. Nigeria. FAO fisheries circular No.770. 29. FAO, Rome. 1990;193.

3. Fagbenro, OA. Predator control of overpopulation in cultured tilapias and the alternative uses for stunted tilapias in Nigeria. (Bolivar, R.B., Mair, G.C and Fitzsimmons, K. eds.). Manila, Philippines. September 12-16, 2004. Proceedings of the Sixth International Symposium on Tilapia in Aquaculture. 2004;634-647.

4. Dada, AA. Use of Fluted Pumpkin, Telfairia occidentalis leaf powder as feed additive in African catfish, Clarias gariepinus Fingerlings. International Journal of Biological and Chemical Sciences, 2015;9(1):301-307.

5. Citarasu, T. Herbal Biomedicines: A new opportunity for aquaculture industry. Aquaculture International. 2010;18(3):403-414.

6. Bamidele, O., Akinnuga, AM., Olorunfemi, JO., Odetola, OA., Oparaji, CK. and Ezeigbo N. Effects of aqueous extract of Basella alba leaves on haematological and biochemical parameters in albino rats. African Journal of Biotechnology. 2010;9:69526955.

7. Moundipa, PF., Beboy, NSE., Zelefack, F., Ngoula, S., Tsamo, E., Schill, WB. and Monsees, TK. Effects of Basella alba and Hibiscus macranthus extracts on testosterone production of adult rat and bull Leydig cells. Asian Journal of Andrology. 2005;7:411417.

8. Deshmukh, SA. and Gaikwad, DK. A review of the taxonomy, ethnobotany, phytochemistry, and pharmacology of Basella alba (Basellaceae). Journal of Applied Pharmaceutical Science 2014;4(01):153165.

9. Siriwatanametanon, N., Fiebich, BL., Efferth, T., Prietoa, JM. and Heinrich M. Traditionally used Thai medicinal plants: In vitro anti-inflammatory, anticancer and antioxidant activities. Journal of

Ethnopharmacology. 2010;130:196-207.

10. Odugbemi, T. A Textbook of Medicinal plants from Nigeria. University of Lagos Press, Lagos, Nigeria; 2008.

11. Takeuchi, T. Fish Nutrition and Mariculture. In: Watanabe, T, editor. Laboratory Work: Chemical Evaluation of Dietary Nutrients. Department of Aquatic
Biosciences, Tokyo University of Fisheries, Tokyo; 1988.

12. Tacon, AGJ. Essential Nutrients - Proteins and Amino Acids. In: Tacon, AGJ, editors. Standard Methods for the Nutrition of Farmed Fish and Shrimp. Argent Laboratories Press, Redmond, WA, USA. 1990. 13. AOAC. Association of Official Analytical Chemist. Official methods of analysis, $15^{\text {th }}$ Edition., Washington DC; 1990.

14. National Research Council. Nutrient requirement of fish and shrimp, Washington, DC, USA, National academy Press. Washington, DC. 2011.

15. Steel, RGD. and Torrie, JH. Principles and Procedures of Statistics. 2nd ed. New York:

McGraw-Hill; 1980.

16. Duncan, DB. Multiple range and Multiple $\mathrm{F}$ Tests. Biometrics; 1955.

17. Agbaire, PO. Nutritional and Anti-nutritional Levels of Some Local Vegetables (Vernonia amygdalina, Manihot esculenta, Teiferia occidentalis, Talinum triangulare, Amaranthus spinosus) from Delta State, Nigeria. Journal of Applied Science and Environmental Management. 2011;15(4):625-628.

18. Udo, SE., Obi-Abang, M., Okoi, Al. and Akwaji, $P$. Nutrition and anti-nutrition components of two popular lesser known vegetables in farming communities of Cross River State, Nigeria. International Journal of Applied and Natural Sciences. 2013;2(5): 8590.

19. Adepoju, OT. and Oyewole, EO. Nutritional importance and micronutrient potentials of two conventional indigenous green leafy vegetables from Nigeria. Agricultural Journal. 2008;3(5):1-4. 2008.

20. Bhatnagar, A. and Devi, P. Water quality guidelines for the management of pond fish culture. International Journal of Enviromental Science. 2013;3(6):1980-2009.

21. Oladipupo, M., Nwanna, LC., and Fagbenro, OA. Effect of 17 alpha metyltestoserone hormone as sex reversal agent on Oreochromis niloticus fingerlings. . In : Green Economy: A viable Option to Dwindling Oil Revenue (Adekunle, V.A.J., Osho, I.B. and Ogunwande, I.O.- Editors) Proceedings of the 9th Annual Conference of the School of Agriculture andAgricultural Technology, Akure, Nigeria held at The Federal University of Technology, Akure, Nigeria, 30th May and 1st June, 2017, pp. 340-343.

22. Appler, HN. Evaluation of Hydrodictyon reticulatum as protein source in feeds of Oreochromis niloticus and Tilapia zillii. Journal of Fish Biology. 1985;27(3):327-334.

23. Soltan, MA. and El-Laithy, SM. Effect of probiotics and some spices as feed additives on the performance and behaviour of the Oreochromis niloticus. Egyptian Journal of Aquatic Biology and Fisheries 2008;12(2):63-80.

24. Ghosal, I. and Chakraborty, SB. Effects of the aqueous leaf extract of Basella alba on sex reversal of Nile tilapia. Journal Pharmaceutical Science. 2014;4: 459-461. 